تفسير محمد عبده للطير الأبابيل

تفسير محمد عبده للطير الأبابيل

وصلته بمؤلف كتاب الفن القصصي

\title{
عرض وتحليل
}

الأستاذ الدكتور/أنور إبر اهيم منصور

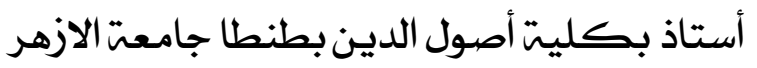

وكليت الاداب جامعت البحرين

\section{المقدمة}

الحمد لله رب العالمين، و الصلاة و السلام على أشرف المرسلين، سيدنا محمد و على آله و أصحابه أجمعين، وبعد:

فقد احتل الأستاذ الإمام محمد عبده مكانة مرموقة في الفكر الإسلامي بما أحدثه من ثورة

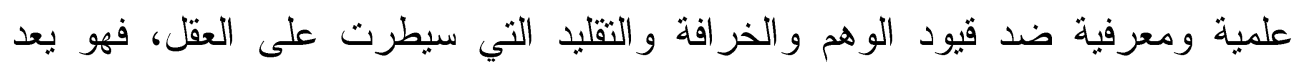
مدرسة شامخة في الإصلاح و التجديد.

قال أحد من كتبو اعنه: تتلخص رسالة حياته في أمرين: الاعوة إلى تحرير الفكر من قيد التقليد، ثم التمبيز بين ما للحكومة من حق الطاعة على الشعب وما للشعب من حق العدالة

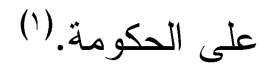
ولقد انفرد رحمه اله في تفسيره بآر اء خاصة لم يسبق إليها ولم يقل بها أحد من أئمة التفسير من قبله. و الخروج عن المألوف في البحث العلمي لا يعد مدحاً لصاحبه و لا قدحاً فيه إلا بعد الوقوف على قيمة ما جاء به من قول.

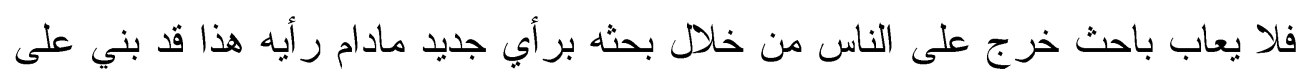
قو اعد و اضحة وبر اهين مؤيدة ولم يصادم في ذلك نقلا صحيحا ولا عقلا سليما.

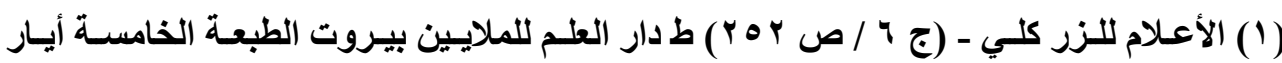




$$
\text { دأنور إبراهيم منصور }
$$

أما إذا كان الأمر على خلاف ذللك؛ فلا قيمة للقول مهما كانت درجة صاحبه من الثهرة وذيوع الصيث؛ إذ الحق لا يعرف بالرجال و إنما يعرف الرجال بالحق.

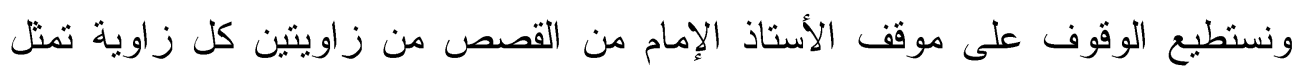

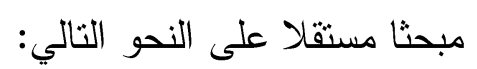
المبحث الأول: تفسير الأستاذ الإمام للمر اد من الطير الأبابيل في سورة الفيل. وتحته مطالب. المبحث الثاني: الصلة بين فكر الأستاذ الإمام وصاحب الفن القصصي في القرآن. وتحته مطالب ثم كانت نهاية المطاف بالخاتمة المتضمنة أبرز النتائج التي توصلت إليها.

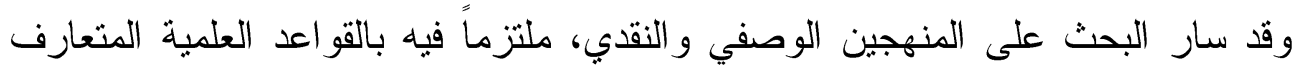
عليها من عزو للآيات القر آنية، وتخريج للأحاديث النبوية، ونسبة كل قول لقائله و غير بلني ذلك...

و الله يعلم قصدي ونيتي، و أسأله أن يجعل هذا العمل خالصاً لوجهه الكريم، وأن يبيض به وجهي يوم تبيض وجوه وتسود وجوه.

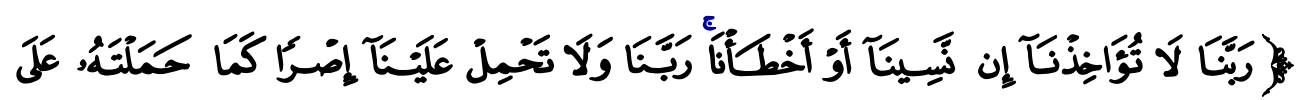

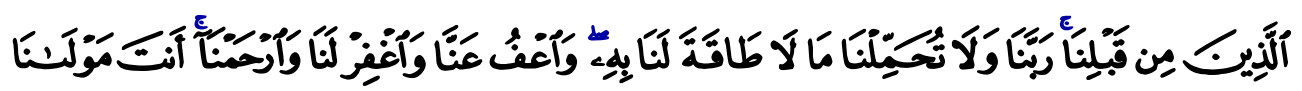

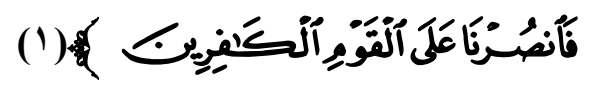


تفسير محمد عبده للطير الأبابيل

المبحث الثاني: تفسير الأستاذ الإمام للمر اد من الطبر الأبابيل.

وتحته المطالب الآتبة:

المطلب الأول: تفسير الأستاذ الإمام للقصة

المطلب الثاني: أثر مقولة الأستاذ الإمام.

المطلب الثالث: حقيقة الهلاك:

المطلب الر ابع: تواتر القصة

من جملة ما انفرد به الأستاذ الإمام رحمه الله من آراء ما نُقل عنه في تفسيره لسورة

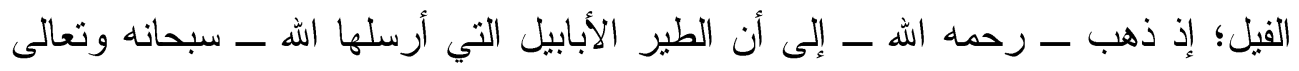

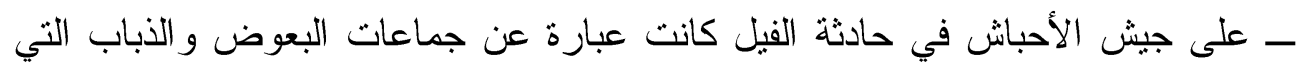
تحمل جر اثثم مرض الحصبة أو مرض الجدري، وأنها ليست على ما برويه المؤرخون

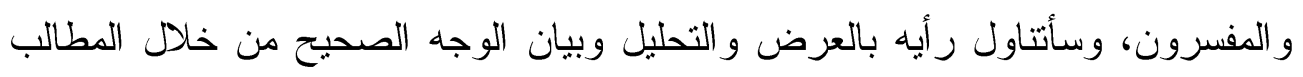
الآتية:

\section{المطلب الأول: تفسبر الأستاذ الإمام للقصة}

قال الأستاذ الإمام محمد عبده في تأويله لقصة أصحاب الفيل:

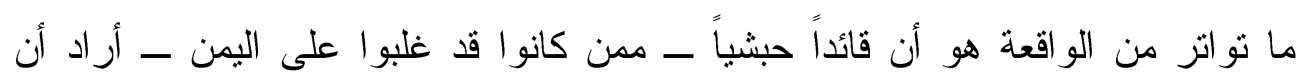
يعتدي على الكعبة المشرفة ويهدمها ليمنع العرب من الحج إليها أو ليقهرهم ويذلهم، فتوجه بجيش جر ار إلى مكة لذللك، واستصحب معه فيلاً أو فيلة كثيرة زيادة في الإزهاب

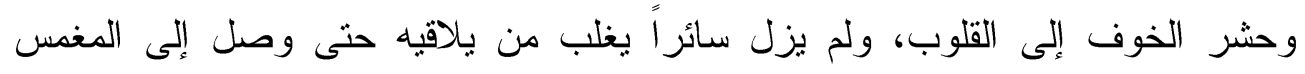

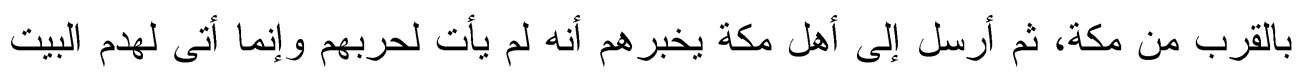

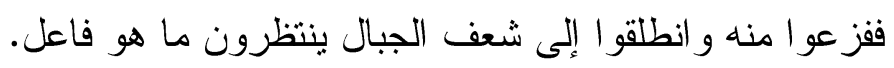
وفي البوم الثاني فنا في جند الجيش داء الجدري و الحصبة. قال عكرمة: وهو أول

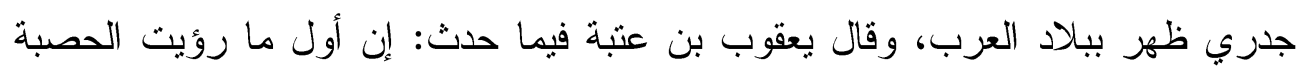
و الجدري ببلاد العرب ذلك العام، وقد فعل ذلك الوباء بأجسامهم ما يندر وقوع مثله، فكان

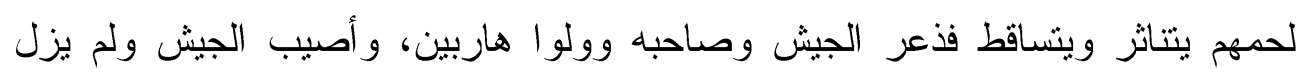
يسقط لحمه قطعة قطعة و أنملة أنملة حتى انصدع صدره ورمات. 
هذا ما اتفقت عليه الروايات ويصح الاعتقاد به، وقد بينت لنا السورة الكريمة أن ذلك الجدري أو تلك الحصبة نشأت من حجارة يابسة سقطت على أفراد الجيش بواسطة فرق عظيمة من الطبر مما برسله الله مع الريح. فيجوز للك أن تعتقد أن هذا الطير من جنس البعوض أو الذباب الذي يحمل جر اثثم بعض يرله

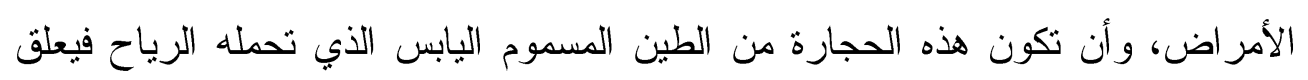
بأرجل هذه الحيو انات، فإذا اتصل بجسد دخل في مسامه، فأثار فيه تللك القروح التي نتانهي

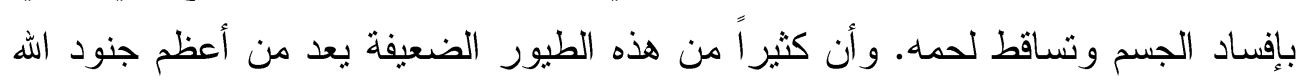
في إهلاكك من يريد إهلاكه من البشر، وأن هذا الحيوان الصغير الذي يسمونه الآن بالميكروب لا يخرج عنها. وهو فرق وجماعات لا يحصي عددها إلا بارئها..

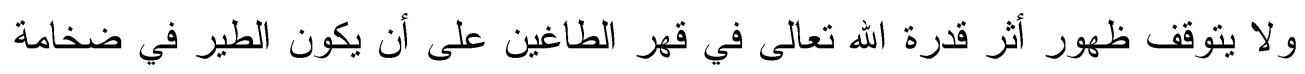

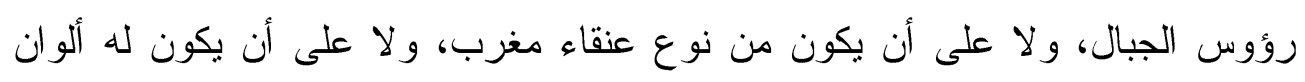

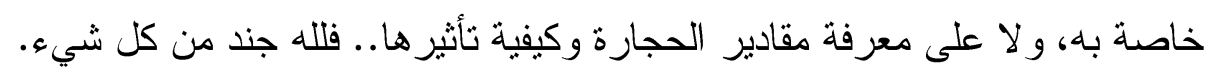
وفي كل شيء له آية... تدل على أنه الواحد

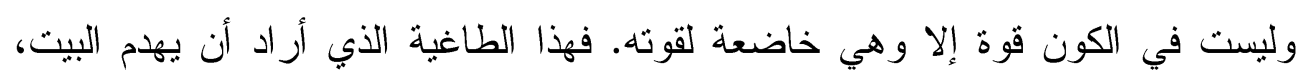

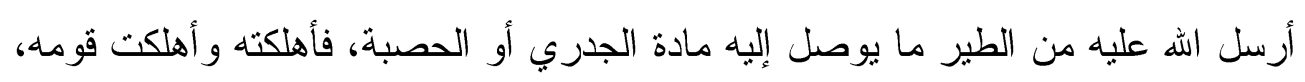
قبل أن يدخل مكة. وهي نعمة غمر الله بها أهل حرمه على وثنيتهم حفظاً لبيته، حتى لئى

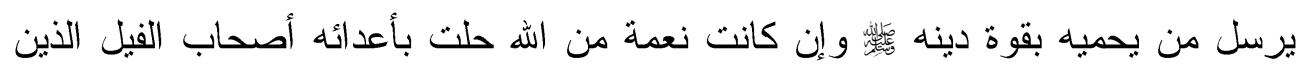
أر ادوا الاعتداء على البيت دون جرم اجترحه، و لا ذنب اقترفه.

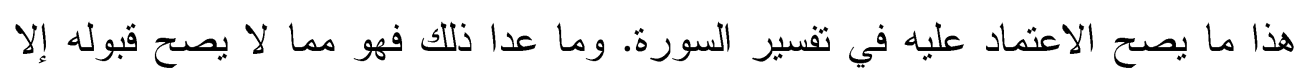
بتأويل إن صحت رو ايته. 
تفسير محمد عبده للطير الأبابيل

ومما تعظم به القدرة أن يؤخذ من استعز بالفيل وهو أضخم حيوان من ذوات الأربع

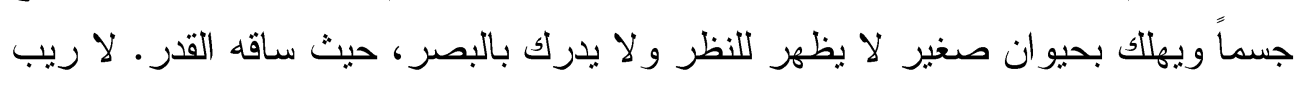
عند العاقل أن هذا أكبر و أعجب و أبهر !!. (1) هذا ما قاله الأستاذ الإمام رحمه الله، وهو كلام انفرد به رحمد الله. المطلب الثاني: أثر مقولة الأستاذ الإمام.

كان لهذه المقولة أثز ذائع في البيئة الثقافية آنئذ، فانقسم الناس حولها ما بين مؤيد متابع، وما بين معارض ناقد. ومن أبرز من تابع الإمام على رأيه الأستاذ عباس العقاد إذ كثب مقالاً في صدر أحد أعداد مجلة الرسالة عن الصلة بين القرآن والنظريات العلمية قسم المجتهدين الآنئ المحدثين الباحثين عن التوفيق بين القر آن و الكشوف العملية إلى فريقين: فريق حاول تفسير القرآن بناء على النظريات العلمية التي لا تز ال محل نظر واجتهاد وهذه محاولات غير مأمونة العاقبة، وفريق آخر وفق بين العلم والقرآن بطريقة معقولة مقبولة، وضرب المثال بفعل

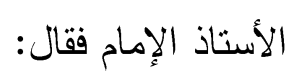

وقد تكون محاو لات التوفيق مأمونة معقولة كقول الأستاذ الإمام الشيخ محمد عبده رحمه الله في تفسير الطير الأبابيل بجر اثيم الأمر اض التي تسمى بالميكروبات، فالميكروبات موجودة لا شك فيها و الإصابة بها محققة كذلك في مشاهدات مجربة لا تقبل الجدال، فإذا قال المفسر كما قال الأستاذ الإمام أن هزيمة أصحاب الفيل ربما كانت من فعل هذه الجر اثثم فللك قول مأمون على الجواز و التزجيح، ولكنه غير مأمون على الجزم و التوكيد؛ لأن الحفريات التاريخية قد تكشف لنا غدا عن حجارة من سجيل أصيب بها أصحاب الفيل

فجعلتهم كعصف مأكول. (r) فسياق كلام الأستاذ العقاد بدل على قبوله هذا التقسير على سبيل الجواز و التزجيح.

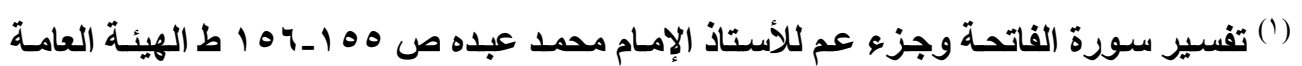

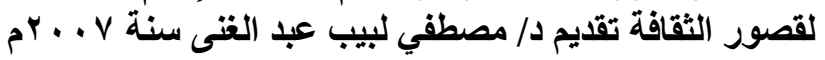

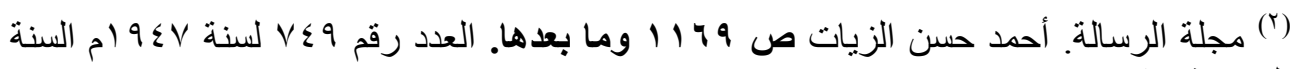
الخامسة عشرة. 


$$
\text { د/أنور إبراهيم منصور }
$$

وفي موضع آخر يعلن الأستاذ العقاد تبعيته المطلقة لهذا المسلك من التفسير، بل ويعضد ذللك بالدليل.

ففي ثنايا حديثه عن خصال عبد المطلب جد النبي أثثاء ذلك تطرق إلى قصة أبرهة عندما قدم لهدم الكعبة قائلا:

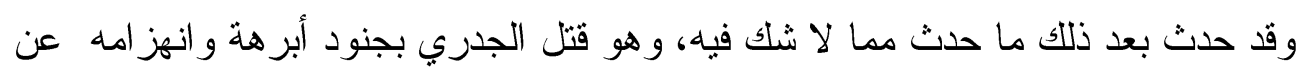
البيث وخوفه من أن يتقام إليه بأذى، و إنه لخبر قد يسكل إنكاره على المتحذلقة من أدعياء التاريخ الذين يجمعون التمحيص كله في الإنكار لو لا أن حديث الجدري الذي فنشا في سنة

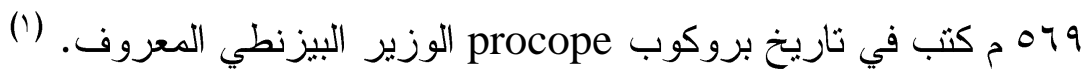
فلئن كان الأستاذ الإمام قد بني كلامه على آثار نقلية واجتهادات عقلية فإن الأستاذ العقاد قد ز اد الأمر توثثقا وتأكيدا بشو اهد علمية وتاريخية.

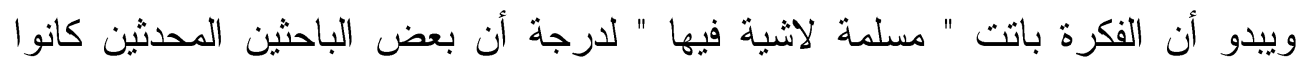

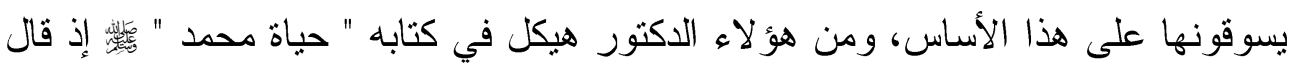
في عبارة و اضحة: كان وباء الجدري قد تفشى بالجيش وبدأ يفتك به، وكان فتكه ذريعاً لم يعهذ من قبل قط،

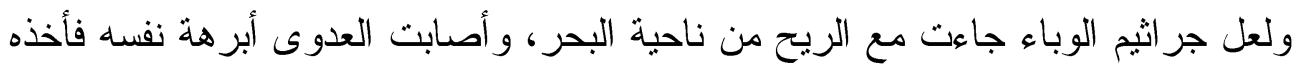

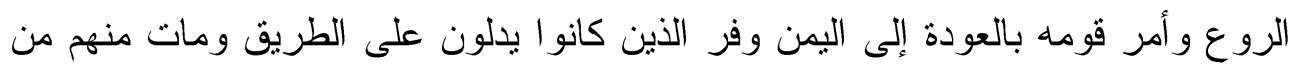
مات، وكان الوباء يزداد كل يوم شدة ورجال الجيش يموت منهم من يموت كل يوم بغير حساب (r) هذا عن المو افقين. أما عن المخالفين لر أى الأستاذ الإمام فهم من الكثرة بمكان، تمثلت في جمهرة المفسرين قديما وحديثًا. ولنتأمل هنا في كلام الأستاذ الإمام وما كتب عنه من خلال الصفحات التالية

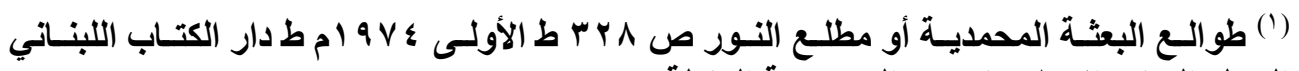
المجلا السابع الإسلاميات من المجموعة المعلة الكاملة

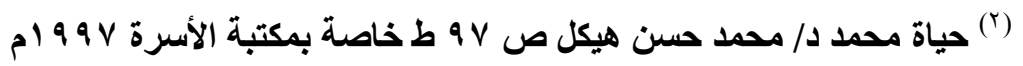

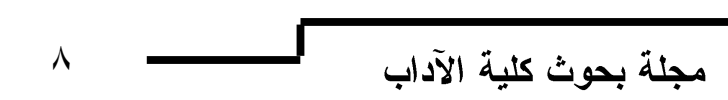


تفسير محمد عبده للطير الأبابيل

\section{المطلب الثالث: حقبقة الههلك:}

أثار الأستاذ الإمام في كلامه إلى أن السورة الكريمة بينت أن ذلك الجدري أو تلك الحصبة نشأت من حجارة يابسة سقطت على أفر اد الجيش بو اسطة فرق عظيمة من الطير مما يرسله الله مع الريح. ونحن (')نرجع إلى السورة فلا نر اها تبين شيئًا أو تقول شيئًا عن الجدري أو الحصبة. لم تعرض السورة لشيء من ذلك. ونتساءل عن حقيقة الهلاك بالحجارة: هل كان بتلك الحجارة ذاتها ومن غير توسيط شيء

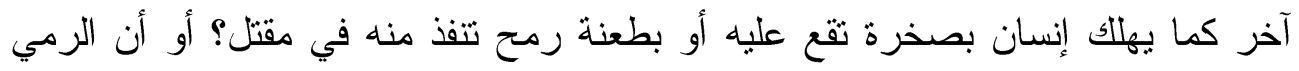
بنلك الحجارة كان ينشأ عنه مرض فتاك يكون بسببه الهلاك؟ ثم ما هي حقيقة ثلأك

$$
\text { الحجارة بن }
$$

الذي قاله المفسرون و المؤرخون أن هذه الحجارة كانت قطعاً صغيرة من طين يابس شديد صلب، وذلك هو معنى السجيل، فهي من طبيعة الطبن، وليست من طبيعة أحجار الجبال، وقد عبر عنها بحجارة نظر اً إلى يبسها وشدتها وصلئ وصلابتها. هذا ما تشهد به اللغة في معنى السجيل، وهو ما تدل عليه آيات قر آنية تحدثت عما رمى به قوم " لوط " عليه السلام من مثل ذللك، مما كان به هلاكهم كذلك: قال تعالى بـ فَكًَّا

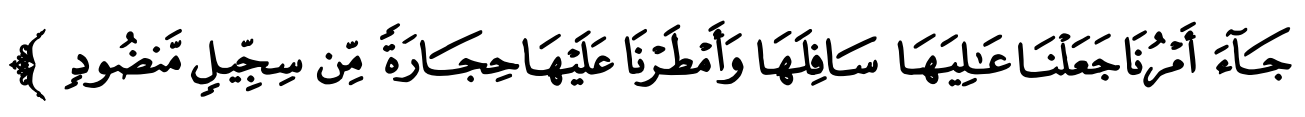

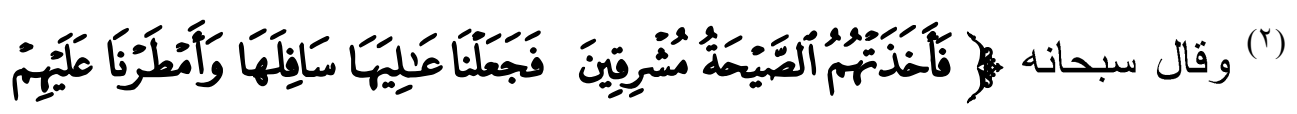

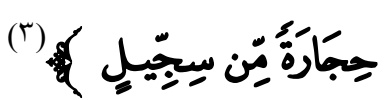

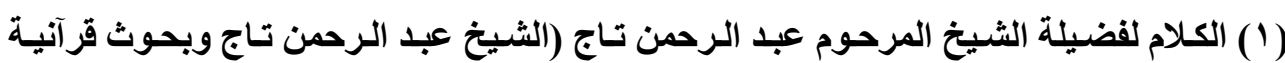

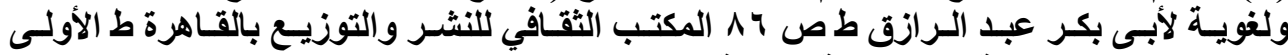

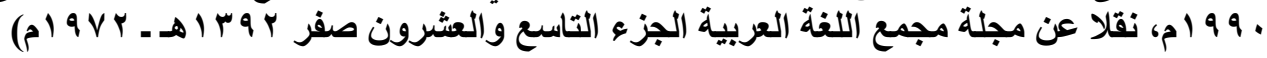

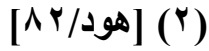

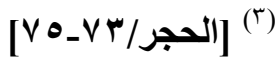

مجلة بحوث كلية الآداب 
دأنور إبراهيم منصور

وفي سورة ثالثة بيان عن ثللك الحجارة التي رمى بها قوم لوط أنها من الطين،

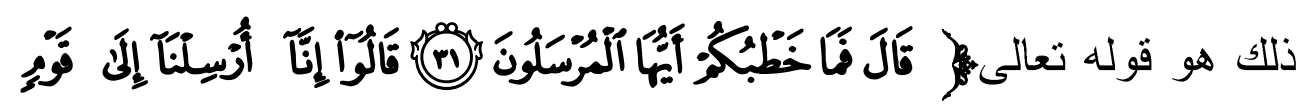

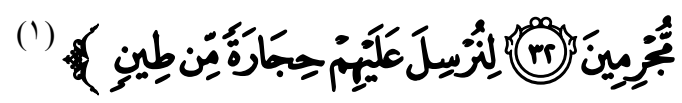

ألا يعد ثفسير الأستاذ الإمام للطير الأبابيل في هذا الموضع على النحو المذكور صرفاً للألفاظ عن ظو اهرها المر ادة إلى معان أخرى !؟ الإنى

\section{المطلب الرابع: تواتر القصة}

نلحظ هنا أن الأستاذ الإمام قد ردد عبار ات: التو اثر، و المتو اتر ، وما اثفقت عليه الروايات،

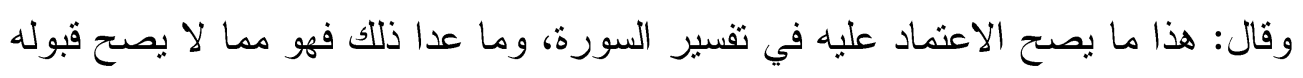
إلا بتأويل إن صحث روال مذايته.

ونحن نقول (r): إن حادثة مرض الجدري أو الحصبة وفشوه في الجيش لم تتفق عليها

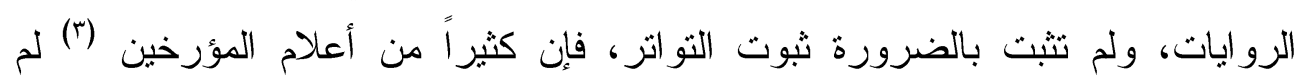

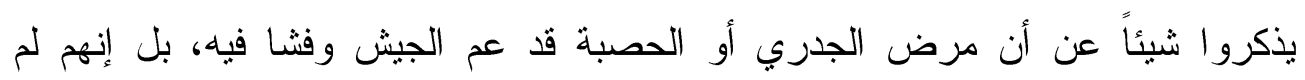

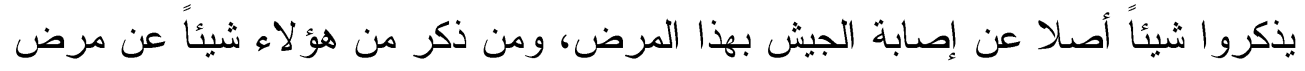
الجدري أو الحصبة لم يذكر أنه أصيب به أحد غير أبرهة. إنه بعيد جداً أن تكون إصابة الجيش الحبشي بمرض الجدري هكذا إصابة عامة وبائية ثم يسكت عنها ويغفل أمرها أولئك العلماء! إذ أنها تكون جديرة أن بروى أخبارها كل معنى بهن بحفظ الأحداث التاريخية العظيمة، و لاسيما حادثة كحادثة الفيل.

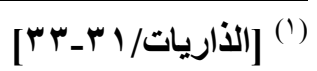

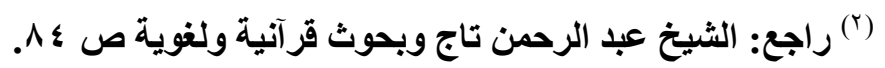

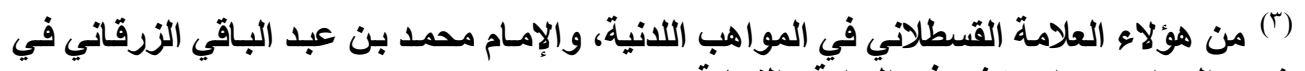
شرح المواهب، وابن كثير في البّاية و النهاية.

1. مجلة بحوث كلية الآداب 
تفسير محمد عبده للطير الأبابيل

\section{روابة عكرمة:}

يستتد الأستاذ الإمام في رأيه على رواية منسوبة إلى عكرمة رضي الله عنه تقيد فشو الجدري في بلاد العرب وقتنئ. و هذه الرواية ليست محل اتفاق بين المؤرخين وأرباب السير، حتى إن رجلاً كابن الأثير

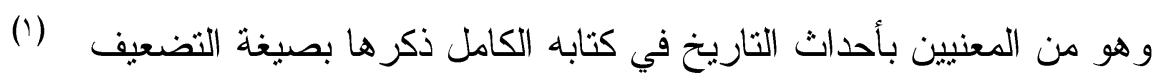

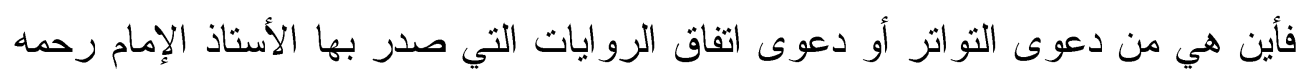
اله كلامه!؟ وعلى فرض صحتها فهي لا تدل على إصابة الجيش كله بالجدري! وختاما نسجل أن كلامنا هذا ليس بقادح في الأستاذ الإمام ولا في قيمته العلمية، وندرك لهابه ونقدر دو افع المدرسة العقلية التي كان الأستاذ الإمام رحمه الله على رأسها في تلك الحقبة سعيها إلى تضييق الغيبيات في تفسير القر آن الكريم ومحاولتهم ربطها بالمألوف من السنن الكونية، وذلك في سبيل مواجهة النزعات الخرافية التي كانت تسبطر على العقل،

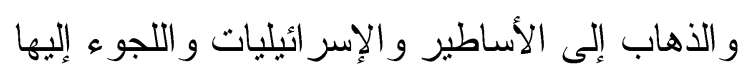

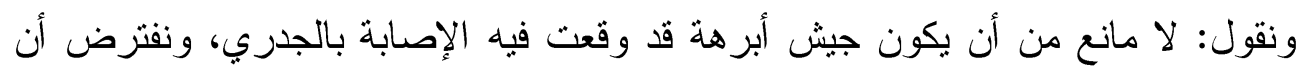

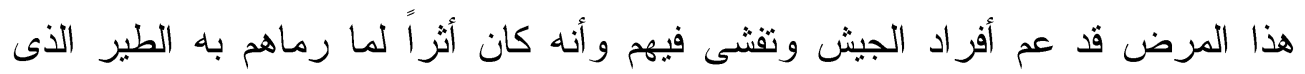
أرسله الله عليهم. أرن.

لكن يجب أن يكون ذلك كله على أساس أن تكون ألفاظ الطير و الرمي و الحجارة الواردة في السورة مأخوذة في معناها الظاهر الذي يتبادر إلى الذهن من تلك الألفاظ.

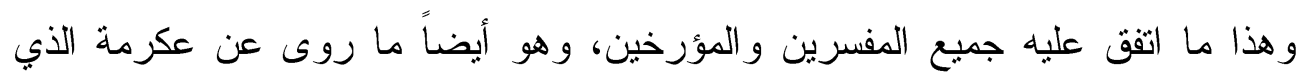
يستند إلى روايته المرحوم الثيخ محمد عبده. (r) النه

(1) الكامل في التاريخ. عز الدين ابن الأثير ص ץ ب ـ ـ وما بعدها، ط دار الكتاب العربي، بيروت ـ

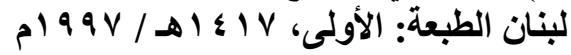

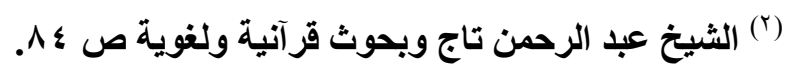


د/أنور إبراهيم منصور

المبحث الثاني: صلة الأستاذ الإمام بمؤلف كتاب الفن القصصي في القرآن:

وتحته عدة مطالب:

المطلب الأول: القصص القر آني والوقائع التاريخية :

المطلب الثاني: القصص التمثيلي.

المطلب الثالث: الالتزام بالصدق والحمل على الاعتقاد بالجزئيات

لا تعنى إثادة القرآن بالعقل و إعلائه من شأنه أن يتجرد صاحبه من كل قيد ديني وينطلق الحقل ليقرر ما شاء وقت ما يشاء، وذلك بحجة حرية العقل و الفكر! هذه ليست حرية، بل بل بله

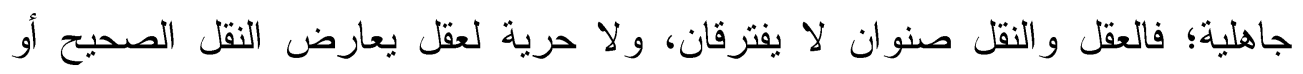

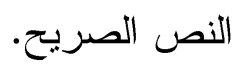
في سنة Vا9 ام تقدم الأستاذ محمد أحمد خلف الله ('المعيد بكلية فؤاد الأول (القاهرة حالياً) برسالة علمية لنيل درجة الدكتور اه موضعها: الفن القصصي في القرآن (؟)، وقد

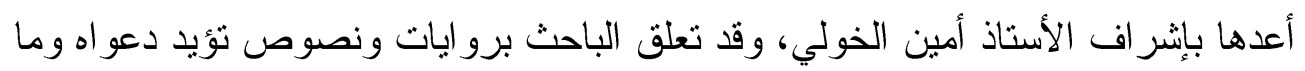
ذهب إليه من فكر بتزاث الأستاذ الإمام محمد عبده، وكان كثير الاستشهاد به في ردوده على منتقديه.

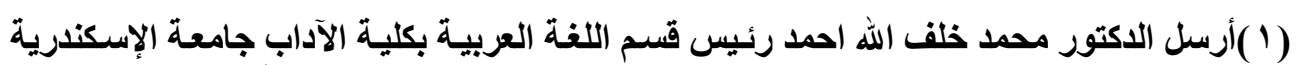

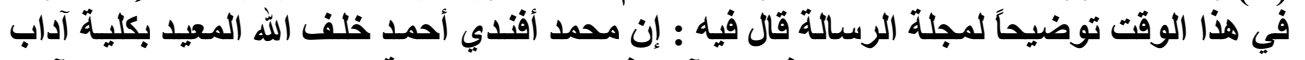

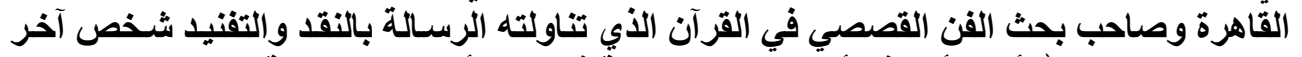

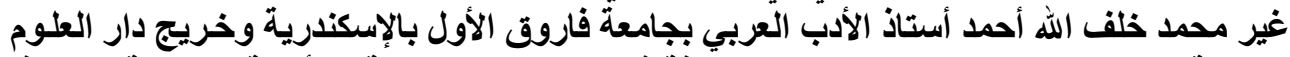

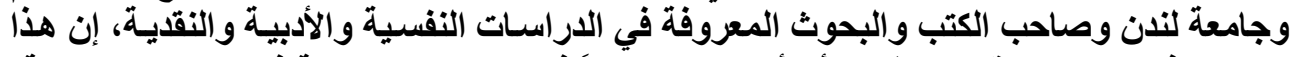

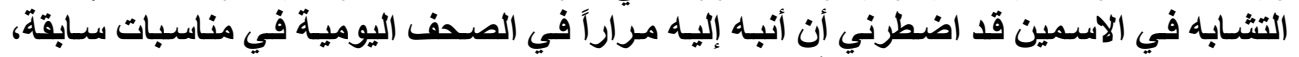

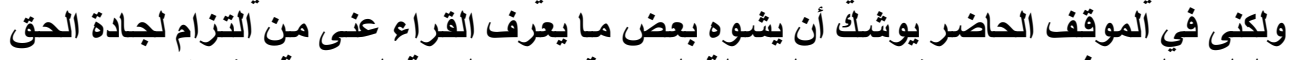

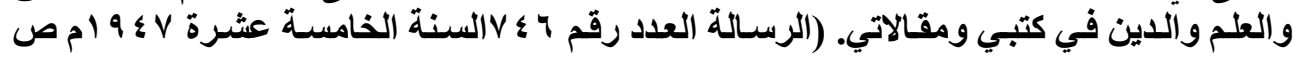

(1170/117

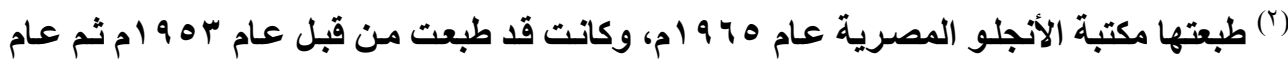

. $190 \mathrm{~V}$

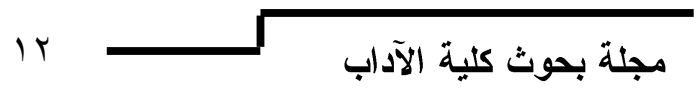


تفسير محمد عبده للطير الأبابيل

وقد دفعني كثرة اعتماد خلف الله في كلامه على نقول نسبها إلى الأستاذ الإمام إلى البحث الإبث

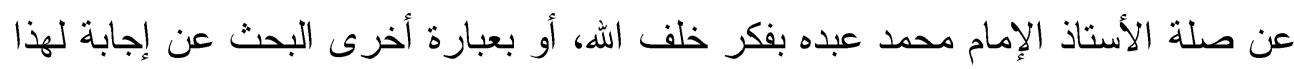

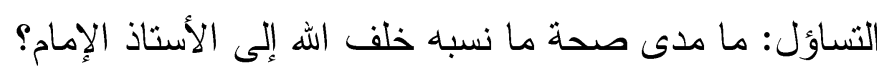

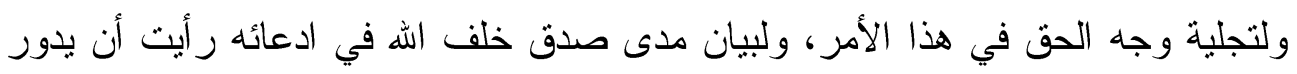

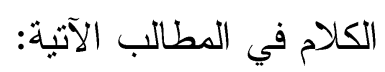

\section{المطلب الأول: القصص القر آني و الوقائع التاريخية:}

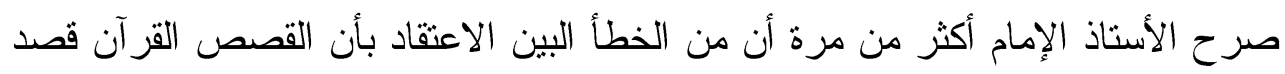

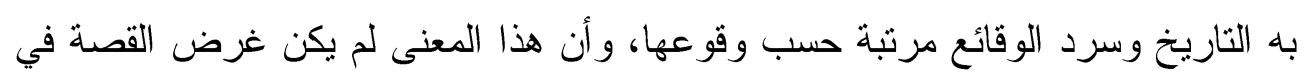

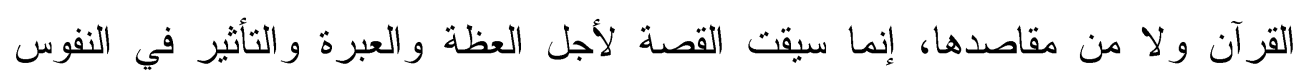

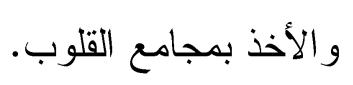

أكد الأستاذ الإمام على هذا المعنى في كثبر من المو اضع ومنها قوله:

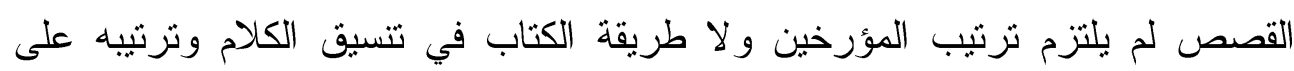

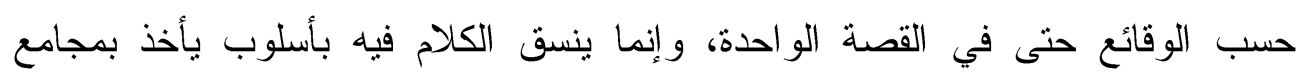

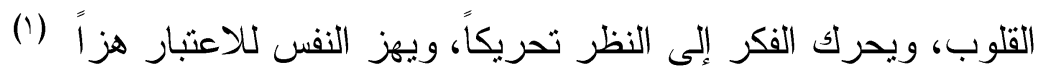

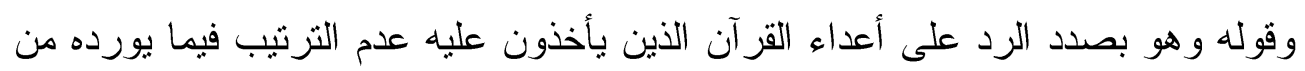

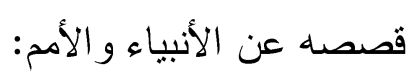

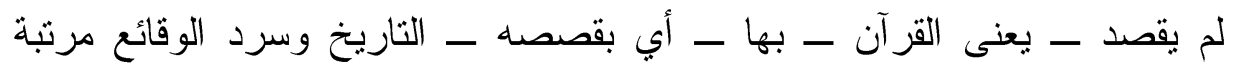

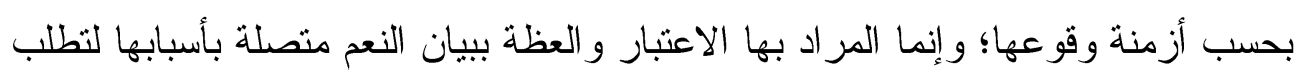

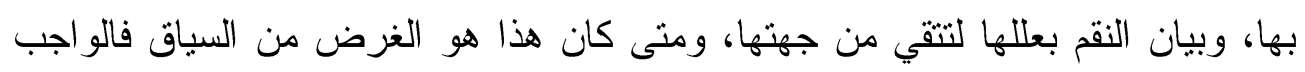

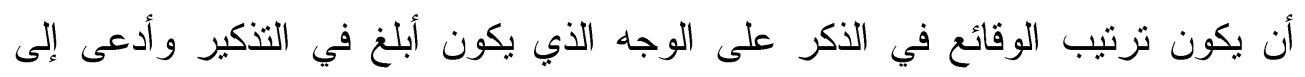
(†) الثأثنر

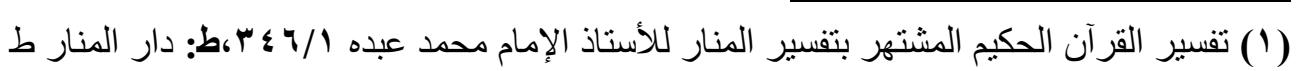

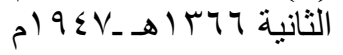

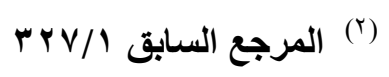


و أبان الإمام أن المقصود الأعظم من القصص العضور العظة والاعتبار لا التاريخ و الزمن، و اعتبر مجيء القصص في القر آن على هذا النمط ضربا من وجوه الإعجاز العلمي فقال:

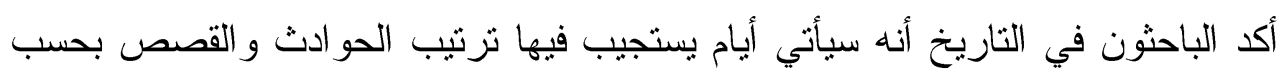

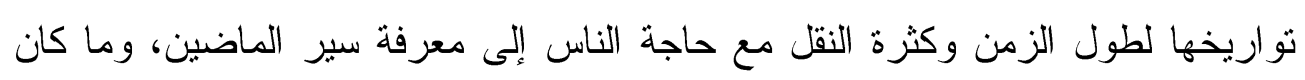
لها من النتائج و الآثار في حال الحاضرين. وقالوا: إن الطريق إلى ذلك هو أن ننظر في كل حادثة من حوادث الكون كالثورات و الحروب وغيرها ونبين أسبابها ونتائجها من غير تفصيل ولا تحديد لجزئين فئات الوقائع

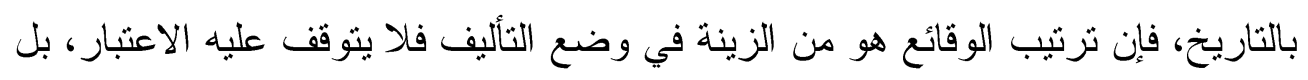

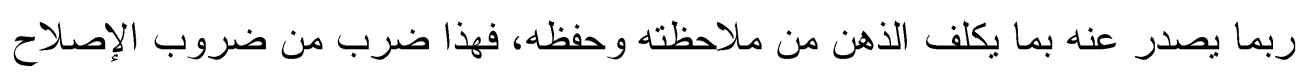

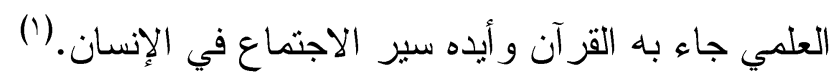
وقال في سياق حديثه عن صلة القصص القر آني بقصص أهل الكتاب: يظن كثير من الناس الآن ـ كما ظن كثير ممن قبلهم - أن القصص التي جاءت في القرآن يجب أن تثفق مع ما جاء في كتب بنى إسرائيل المعروفة عند النصارى بالعهد

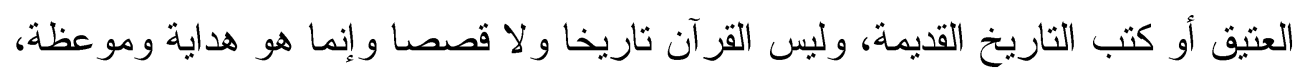

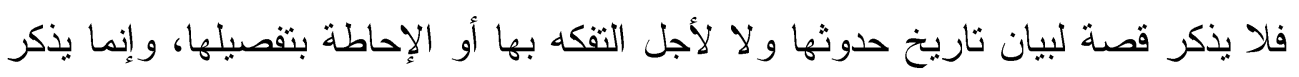

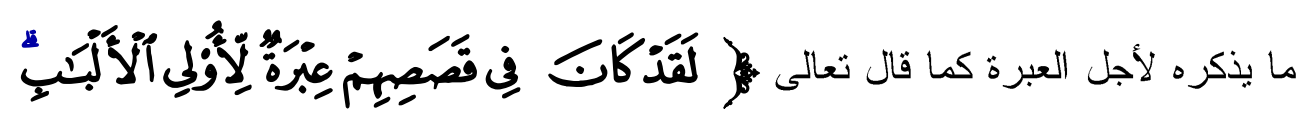

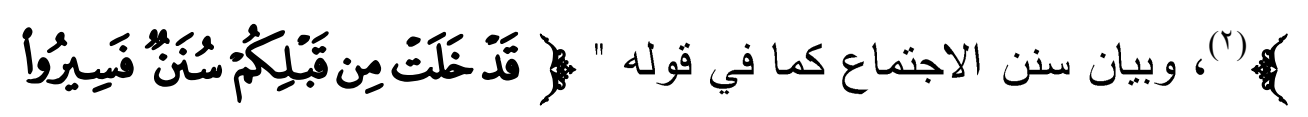

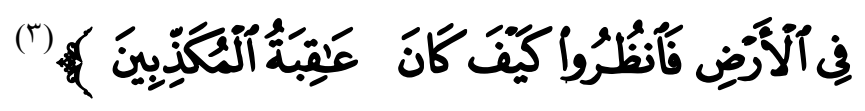

$$
\begin{aligned}
& \text { r (1) (السابق rv/l) }
\end{aligned}
$$

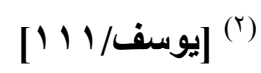

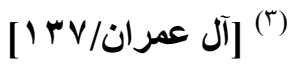


تفسير محمد عبده للطير الأبابيل

ويعرض الأستاذ الإمام المسألة في صورة شبهة ويجيب عنها في تفسير قوله

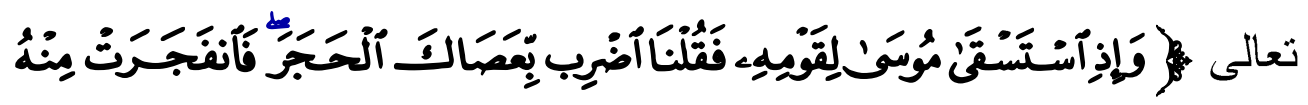

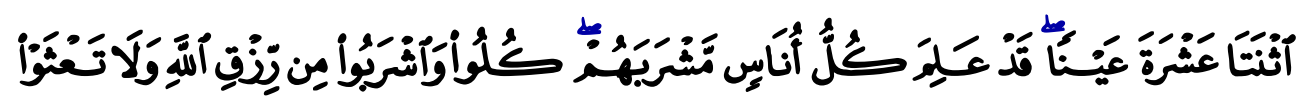

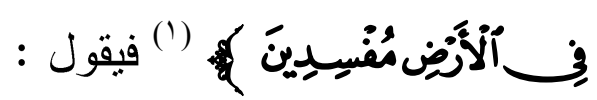

إن كثيراً من أعداء القرآن يأخذون عليه عدم الترتيب في القصص، ويقولون هنا إن الاستسقاء وضرب الحجر كان قبل التيه وقبل الأمر بدخول تلك القرية، فذكر هنا بعد تلك الوقائع.

و الجو اب عن هذه الثبهة يفهر مما قلناه مراراً في قصص الأنبياء والأمم الواردة في القز آن وهو أنه لم بقصد بها التاريخ وسرد الوقائع مرتبة بحسب أزمنة وقوعها، و إنما

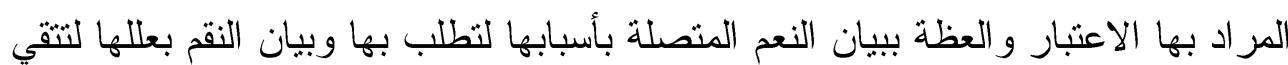

من جهنها. (r) (1)

فخلاصة ما ذهب إليه الأستاذ الإمام أن القصص القرآني لا علاقة له بالتاريخ و لا بترتيب الوقائع فليس هذا مقصوده؛ إنما هو للعبرة و العظة وتحريك القلوب، وذلك حتى نرد عادية الأعداء في ادعائهم مخالفة القرآن للوقائع التاريخية، ومخالفته لما ورد في في كتب ونب أهل الكتاب.

ومن ثم يتضح لنا السبب الدافع لهذا القول، وهو يتطابق إلى حد كبير بما علل به خلف الله ما ذهب إليه في قصص القر آن.

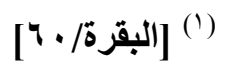

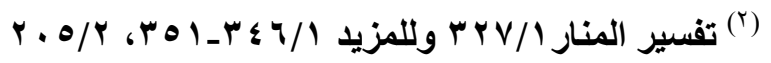

مجلة بحوث كلية الآداب 10 


\section{المطلب الثاني: القصص التمثيلي.}

مما يجب ذكره في موقف الإمام من قصص القرآن: تأويله لبعض القصص وصرفه عن حقيقته، و تفسيره على طريقة التمثيل.

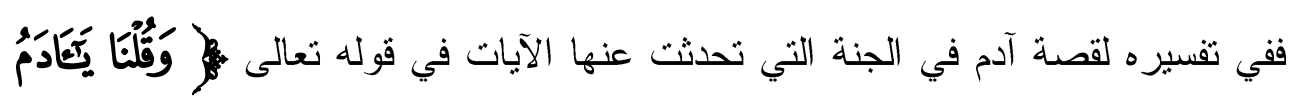

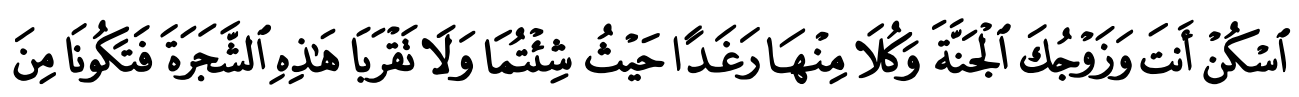

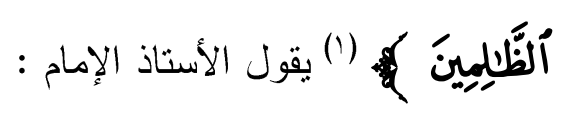

و أما تفسير الآيات على طريقة الخلف في التمثيل فيقال فيه: إن القرآن كثير أ ما يصور المعاني بالتعبير عنها بصيغة السؤال و الجواب أو بأسلوب الحكاية لما في ذلك من البيان

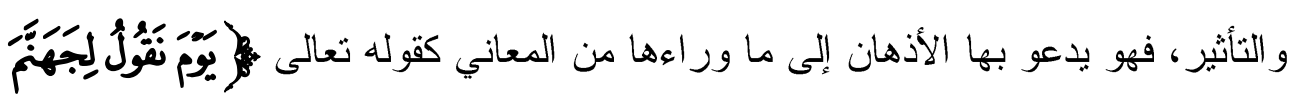

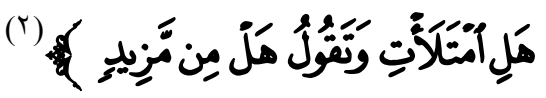

فليس المر اد أن اله تعالى يستقهم منها وهى تجاوبه و إنما هو تمثيل لسعتها وكونها لا تضيق بالمجرمين مهما كثروا، ونحوه قوله عز وجل بعد ذكر الاستو اء إلى خلق السماء

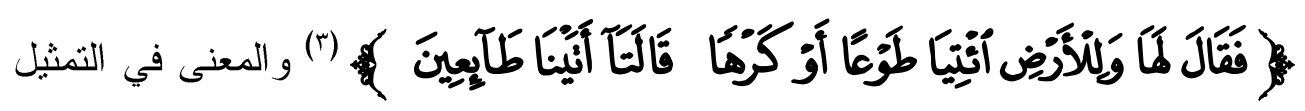
ظاهر

ثم قال وتقرير التمثيل في القصة على هذا المذهب هكذا : إن إخبار اله الملائكة بجعل الإنسان خليفة في الأرض هو عبارة عن تهيئة الأرض وقوى هذا العالم وأرواحه التي بها قو امه ونظامه لوجود نوع من المخلوقات يتصرف فيها فيكون به كمال الوجود في هذه ونه

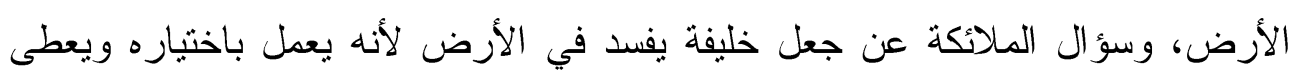

$$
\begin{aligned}
& \text { (1) البقرة: هـ } \\
& \text { [ق/ }{ }^{(r)}
\end{aligned}
$$

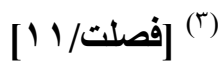


تفسير محمد عبده للطير الأبابيل

استعداداً في العلم و العمل لا حد لهما هو تصوير لما في استعداد الإنسان لذلك وتمهيد الابيل لبيان أنه لا ينافي خلافته في الأرض، وتعليم آدم الأسماء كلها بيان لاستعداد الإنسان لعلم كل شيء في هذه الأرض و انتفاعه به في استعمارها، وعرض الأسماء على ونى الملائكة

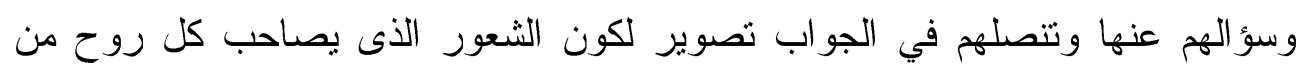

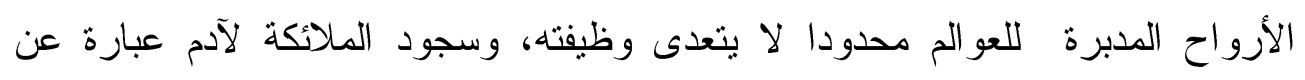

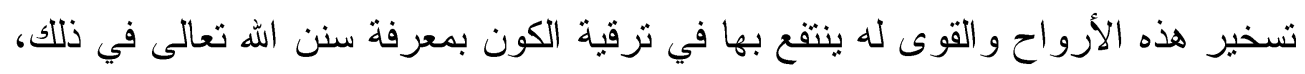

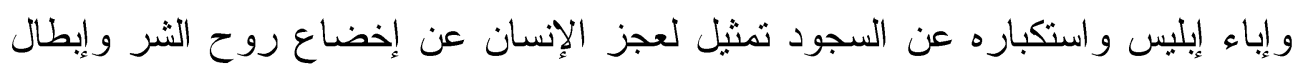

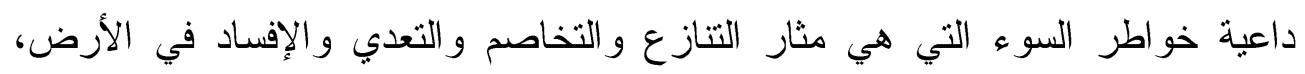

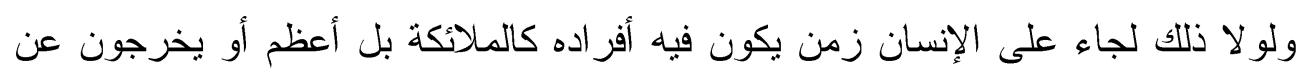
كونهم من هذا النوع البشرى. هذا ملخص ما تقلم في سابق آيات القصة.

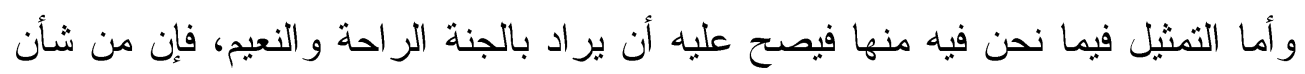

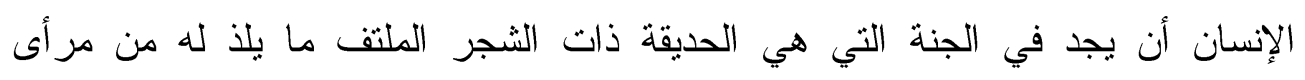
ومأكول ومشروب ومشموم ومسموع في ظل ظليل وهو اء عليل وماء سلسبيل كما قال

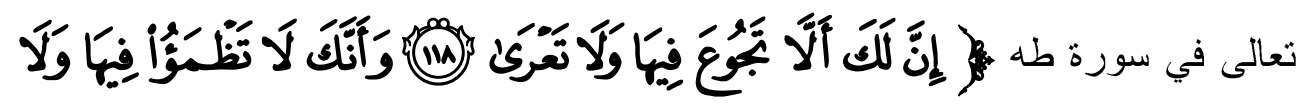

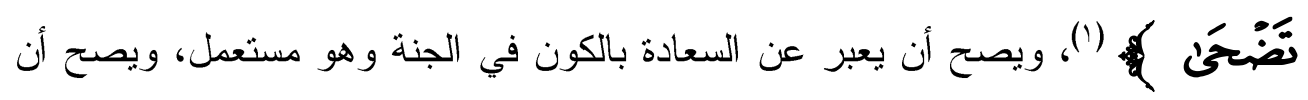
براد بآدم نوع الإنسان كما يطلق اسم أبى القبيلة الأكبر على القبيلة فيقال : كلب فعلت كذا وير اد قبيلة كلب، وكان من قريش كذا يعنى القبيلة التي أبوها قريش، وفي كلام العرب الإبي كثير من هذا.

ويصح أن ير اد بالشجرة معنى الشر و المخالفة كما عبر الله تعالى في مقام التمثيل عن الكلمة الطيبة بالشجرة الطيبة، وفسرت بكلمة التوحيد، و وعن الكلمة الخبيثة بالشجرة الخبيثة

$[119 ، 111 / 4]^{(1)}$

مجلة بحوث كلية الآداب IV 
دأنور إبراهيم منصور

وفسرت بكلمة الكفر (')، وفي الحديث نشبيه المؤمن بالنخلة (؟)، ويصح أن يكون المراد ادئ بالأمر بسكنى الجنة وبالهبوط منها أمر التكوين، فقد تقدم أن الأمر الإلهي قسمان: أمر بر برال تكوين، و أمر تكليف. بالاهن و المعنى على هذا أن اله تعالى كون النوع البشرى على ما نشاهد في الأطوار التنريجية

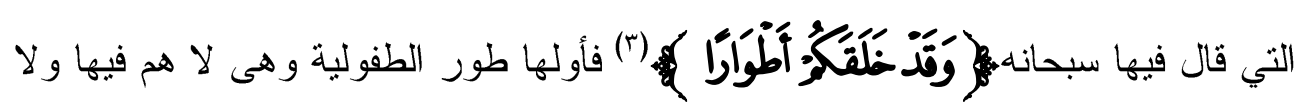
كدر و إنما هي لعب ولهو كأن الطفل دائما في جنة ملتفة الأشجار يانعة الثمار جارية

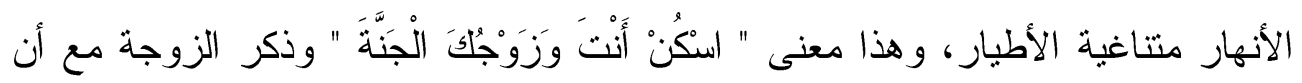

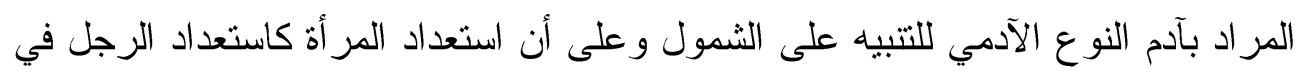

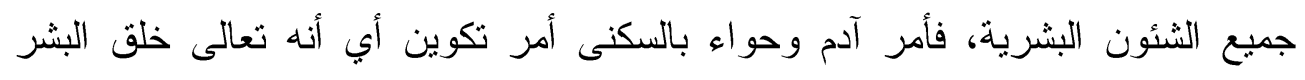
ذكورا و إناثا هكذا، وأمرهما بالأكل حيث شاءع وحئ عبارة عن إباحة الطيبات و إلهام معرفة الخير، و النهى عن الشجرة عبارة عن إلهام معرفة الشر، وأن الفطرة تهدى إلى قبحه

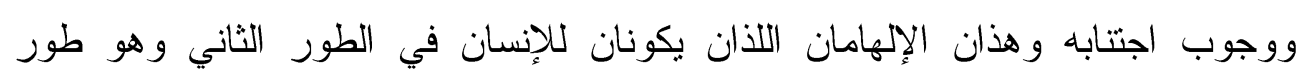

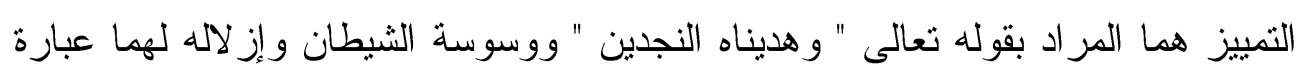

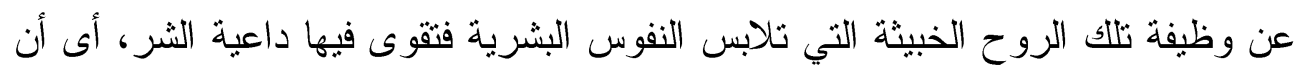

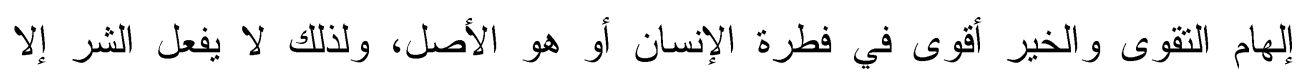
بملابسة الثيطان له ووسوسته إليه، و الخروج من الجنة مثال لما يلاقيه الإنسان من البلاء

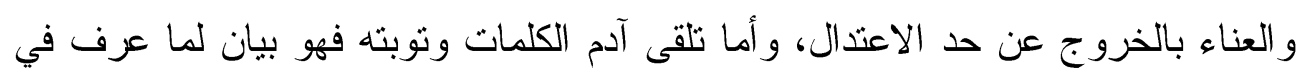

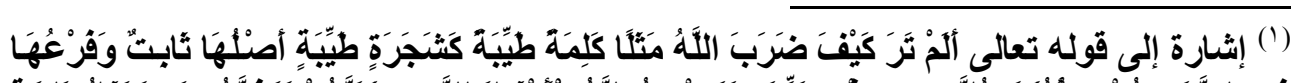

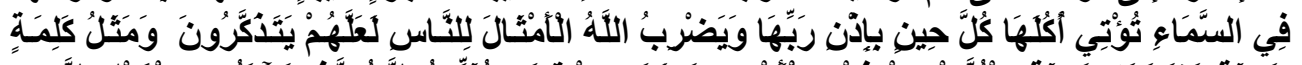

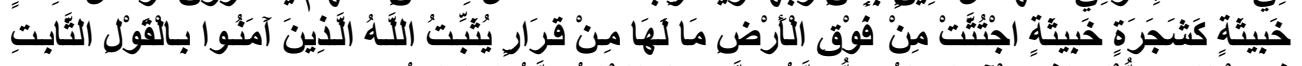

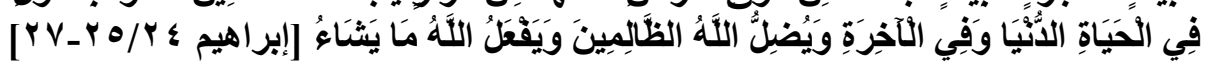

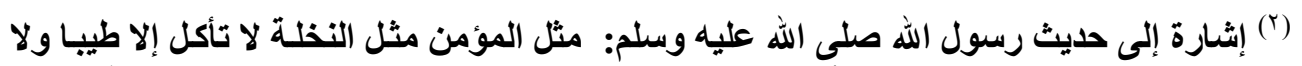

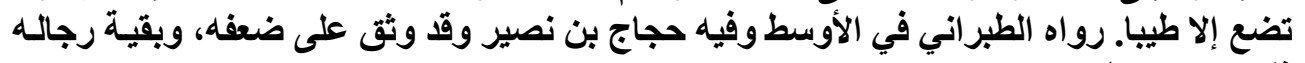

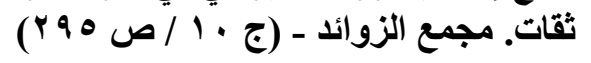

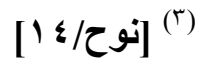


تفسير محمد عبده للطير الأبابيل

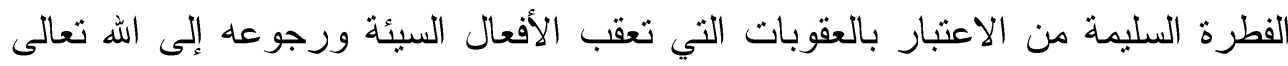

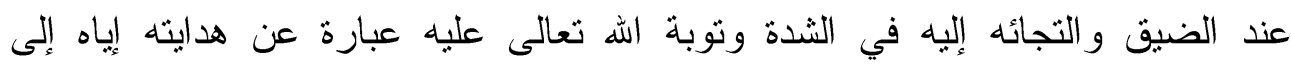
المخرج من الضيق و التقلت من شرك البلاء بعد ذلك الاعتبار و الالتجاء وذكر توبة الله على الإنسان نزد ما عليه النصارى من اعتقاد ان الله نعالى قد سجل معصية آدم عليه و على نبيه إلى أن يأتي عيسى ويخلصهم منها وهو اعتقاد تتبذه الفطرة ويرده الوحي

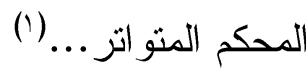
و عقب السيد رشيد رضا على ما ذهب إليه الأستاذ الإمام بقوله اله

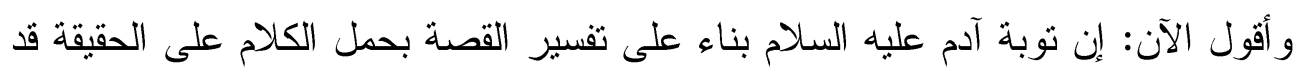
كانت بالرجوع إلى الله و اعتر افه مع حو اء بظلمهما لأنفسهما وطلبهما المغفرة و الرحمة منه تعالى، لا بمجرد تدبر العقل ووزن الخير و الثر بميزان الفكر إلى آخر ما قاله شيخنا

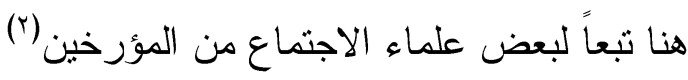
ولو وقف عند هذا الحد لقلنا إنه غير متابع لشيخه في القول بالقصص التمثيلي، لو لا ذهابه

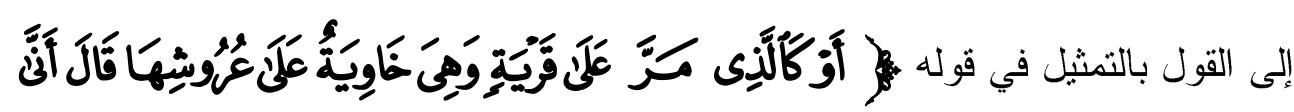

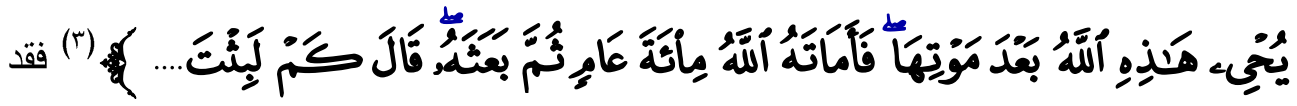
ختم الكلام عن هذه القصة بقوله : ويحتمل أن تكون القصة من قبيل التمثيل.(؛) فبر هن بكلامه على متابعته لشيخه و أستاذه فيما ذهب إليه. ذلكم ما ذهب إليه الثيخ محمد عبده في تأويل قصة آدم في الجنة ومنه ندرك أن الإمام لم لم إنهاه

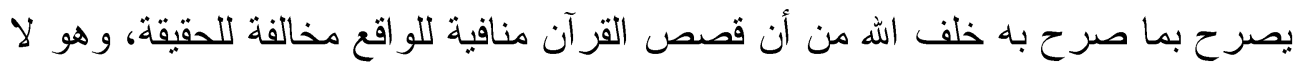

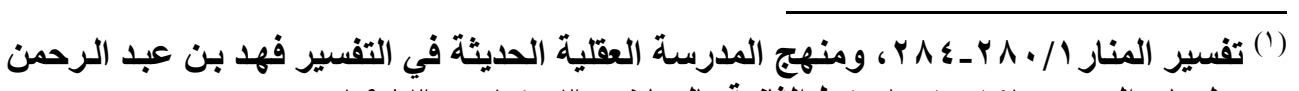

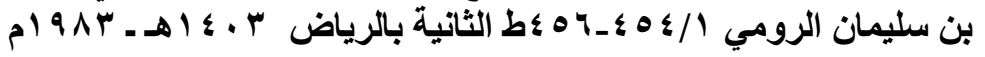

$$
\begin{aligned}
& \text { r^ }
\end{aligned}
$$

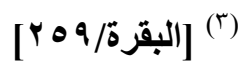

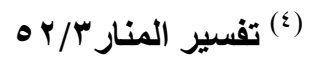


دأنور إبراهيم منصور

شك و افقه في حمل القصة على غبر ظاهر ألفاظها إلى معنى أو معان أخرى لا يدل عليها ظاهر الكلام ومن غير مسوغ لذلك.

وهو مذهب لم يذهب إليه الثيخ محمد عبده في هذه القصة فحسب بل هو منهج سار عليه

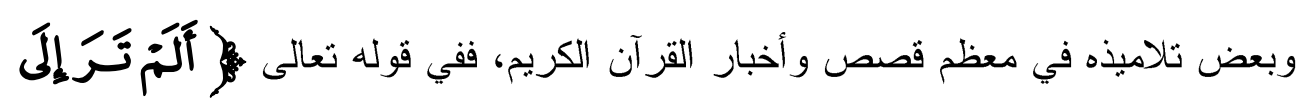

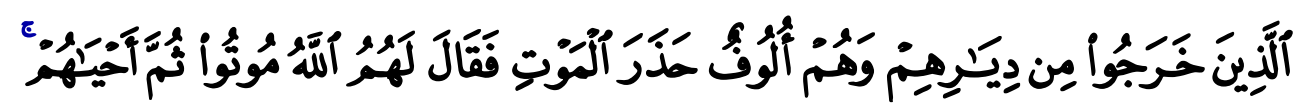

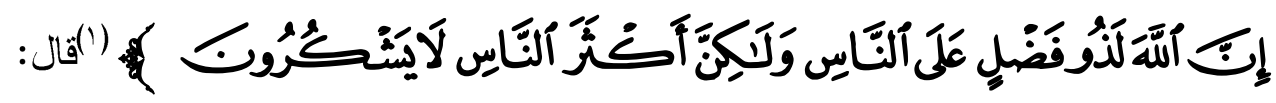
إن هذا مثل لا قصة و اقعة. وتابعه تلميذه بقوله: ولا يشترط أن نكون القصة في مثل هذا التعبير و اقعة بل يصح مثله في القصص التمثلية، إذ ير اد أن من شأن مثلها في وضوحه أن يكون معلوماً حتى كأنه

مرئي بالعين (r) (أن (r) و أرى أنني بحاجة إلى أن أختم الكلام عن هذه النقطة بما قاله الشيخ شلتوت رحمه الله عن هذا المسلك في دراسة القصص القرآني، فلشهادثه قيمة علمية لا بستهان بها في هذا المقام؛ فهو من رجال هذه المدرسة العقلية، و أحد تلامذة الأستاذ الإمام. قال رحمه الله عن منهج المؤولين في القصص القرآني: هو صرف الكلام عن مدلوله اللغوي إلى معنى آخر دون ما بدعو إلى هذا التأويل، وصاحبه قد يُحَكِّ فيه مجرد

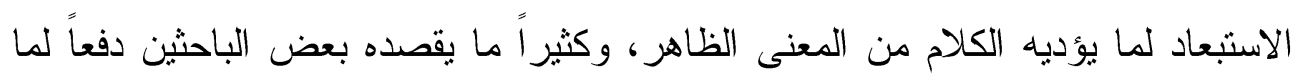
يثيره خصوم القرآن على القرآن - وهو نفس ما ذهب الأستاذ الإمام وتلميذه رشيد رضا - ويدخل في هذا القسم تأويل إحياء الموتى المنسوب لعيسى بالإحياء الروحي،

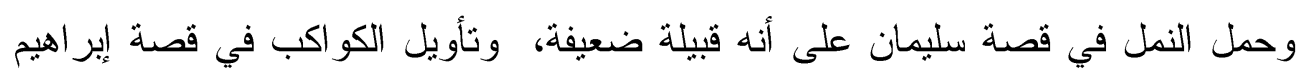
بأنها جو اهر نور انية نور ها عقلي لا حسى....

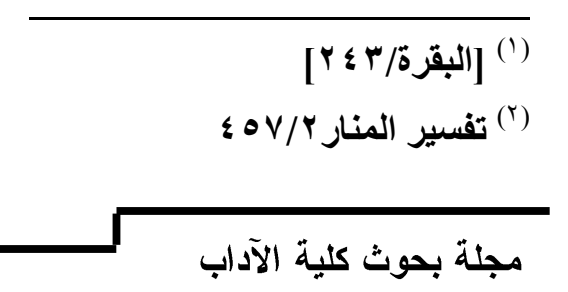


تفسير محمد عبده للطير الأبابيل

ثم ربط الثيخ رحمه اله بين هذا المنهج وبين طريقة الباطنية في تفسير القرآن بقوله:

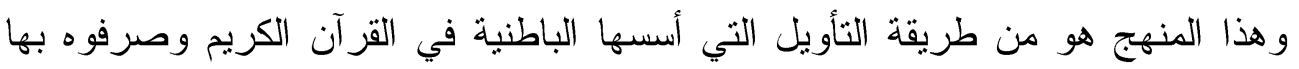
عن دلالته العربية، وفيه احتفاظ بمدلول للكلام وو اقع يدل عليه ولكنه صرف لللفظ عن

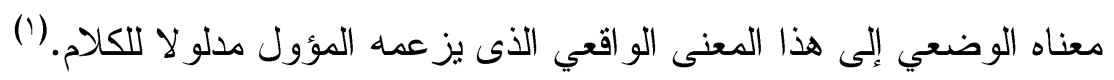

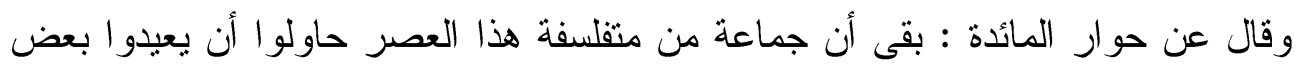

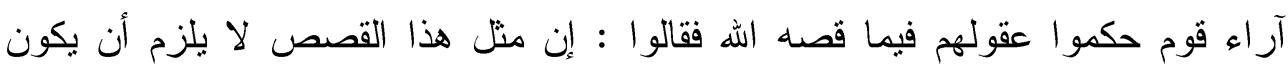
صادقاً يحكى واقعاً صحيحاً، وإنما يجوز أن يكون القرآن جارى فيه معلومات عامة فيه اشتهرت على تعاقب العصور من غير أن يكون لها أصل كوني، وإن القرآن حدث القوم بما يتناقل من معارف مأثنورة وإن لم يكن لها و اقع صحيح، قالو ا ومن الجائز أن يكون ون القرآن هو الذى وضعها ابتذاء بقصد التخييل لغرض صحيح، وهو التأثير على القوم في سبيل اعتناق الحق الذى يدعون إليه، وعليه يكون سؤال الحواريين افتراضا وتخييلا وإجابة عبسى لهم افتراضا وتخييلا و إجابة اله لهم على النحو الذى أجاب به افتر اضا وتخييلا، وكل ما تضمنته هذه الآيات من نسب هي حكايات عن مفروض متخيل لا و اقع ولع

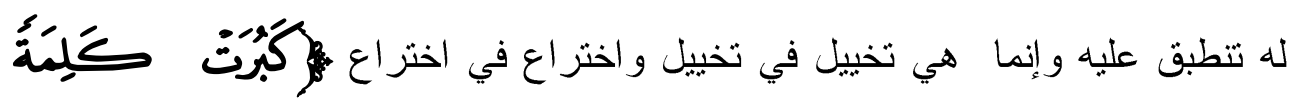

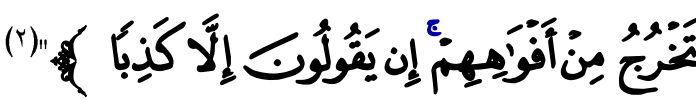

فساد هذا الرأي

انتهى الثيخ شلتوت رحمه الله إلى فساد هذا القول ومنافاته لقدسية القرآن بقوله: و هذه آراء فضلا عما لها من نتائج سيئة تذهب بقدية القرآن من النفوس، وتزيل عنه روعة الحق، وتزلزل قضاياه في كل ما تتاوله من حقائق وتشريع، و أخبار ماضية، و أحو ال مستقبلة، وتقتح لكل إنسان أن يقول في كل هذا : ليس له مدلول و لا و اقع يدل عليه، و إنما هو إما مجار اة لخطأ أو تخييل سيق لمجرد بعث الرغبة أو أو الرهبة أو العظة، وله

( (1) تفسير القرآن الكريم فضيلة الإمام الثيخ محمود شلتوت ص به

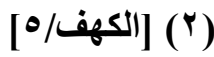

مجلة بحوث كلية الآداب

rI 
دأنور إبراهيم منصور

و تقويم النفوس و إصلاح المجتمعات،و لا يلزم أن يكون لما سيق لهذا الغرض و اقع صحيح بنطبق عليه. هذه الآر اء فضلا عما لها من نلك النتائج السيئة هي فاسدة في ذاتها؛ لأن القرآن عربي نزل بلغة العرب، وقانون اللغة المتواترة يقضى بحمل الكلام على ظاهره، وما تدل عليه ألفاظه من المعاني المعروفة لها عند المخاطبين، ما لم يمنع من ذلك الحمل مانع، فيصار

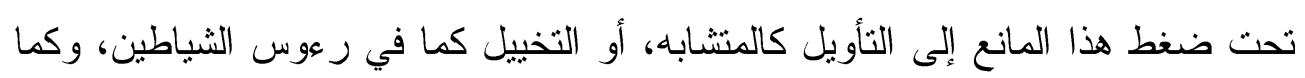

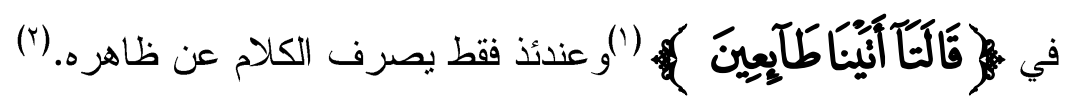
المطلب الثالث: الالتز ام بالصدق والحمل على الاعتقاد بالجزئبات

من أخطر ما ذكره الإمام قوله عن القصص القرآني أنه لا يلتزم الصدق في المنقول،

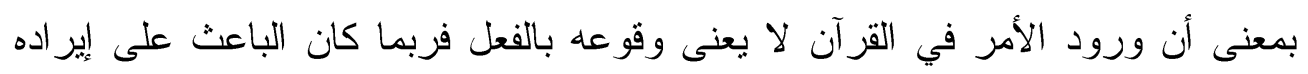
أخذ العبرة و العظة فقط. قال رحمه الله وهو يتكلم عن السحر وحقيقته: ومن البديهي أن ذكر القصة في القرآن لا يقتضي أن يكون كل ما يحكى فيها عن الناس صحيحا! فذكر السحر في هذه الآيات لا يستلزم إثبات ما يعتقد الناس منه، كما أن نسبة الكفر إلى لى

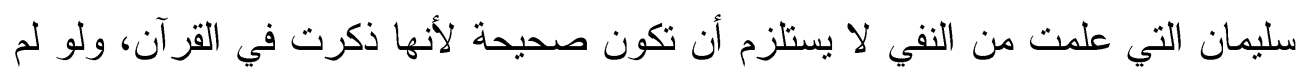
يكن ذكر ها في سياق النفي.

(قال الأستاذ الإمام ما مثاله) بيَّنا غير مرة أن القصص جاءت في القرآن لأجل الموعظة و الاعتبار لا لبيان التاريخ ولا للحمل على الاعتقاد بجزئيات الأخبار عند الغابرين، و إنه

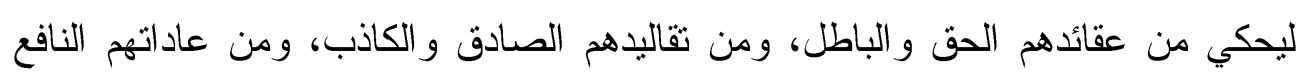
و الضار، لأجل الموعظة والاعتبار، فحكاية القرآن لا تعدو موضع العبرة ولا تتجاوز

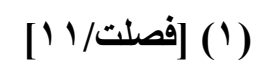

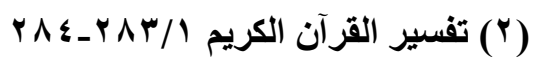

rr مجلة بحوث كلية الآداب 
تفسير محمد عبده للطير الأبابيل

موطن الهداية، ولابد أن يأتي في العبارة أو السياق وأسلوب النظم ما يدل على استحسان الحسن و استهجان القبيح.

وقد يأتي في الحكاية بالتعبيرات المستعملة عند المخاطبين أو المحكي عنهم وإن لم تكن

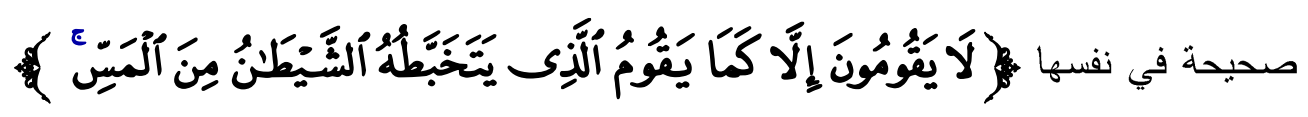

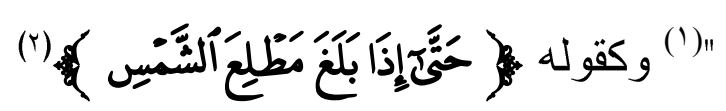

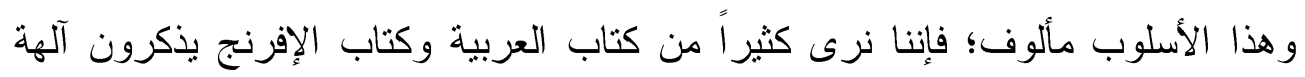
الخير والثر في خطبهم ومقالاتهم لاسيما في سباق كلامهم عن اليونان و المصريين

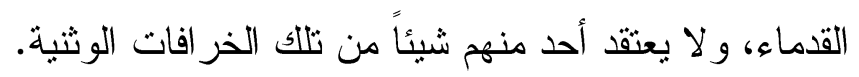
ويقول أهل السواحل: غربت الشمس أو سقط قرص الشمس في البحر أو في الماء، ولا يعتقدون ذلك و إنما يعبرون به عن المبئي. و هذا الكلام يجعلنا نقول: إنه ليس هنالك فارق بين قولي الثيخ محمد عبده و الأستاذ خلف الله؛ فإن رأى الثيخ في قصص القرآن أنها : تمثيل وتخييل وهى للعظة و الهداية، ور أى فئ خلف الله أنها مخالفة للو اقع ومختلقة وهى للعظة و الهداية فهما متفقان على الثطر الثاني، ومتفقان في الثطر الأول على أن ظاهر لفظها غبر مراد وأنها غبر واقعة، عبر الأول عن ذللك بالتمثيل و التخييل و عبر الثاني عنه بالاختلاق... ولنكرر عبار ات الأستاذ الإمام وتلميذه مرة أخرى: فال السيد رشيد: ولا يشترط أن تكون القصة في مثل هذا التعبيز و اقعة، بل يصح مثلك في القصص التمثيلية ويقول: وإن أخبار التاريخ ليست مما بلغ على أنه دين يتبع. ويقول في إحدى القصص: ويحنمل أن تكون القصة من قبيل النمثيل 


$$
\text { د/أنور إبراهيم منصور }
$$

ويقول أخيراً: قد جرى على هذا الأسلوب كتاب القصص المخترعة و الأساطير التي

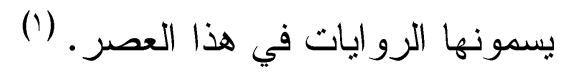
ويقول شيخه: بينا غير مرة أن القصص جاءت في القرآن لأجل الموعظة و الاعتبار لا لان

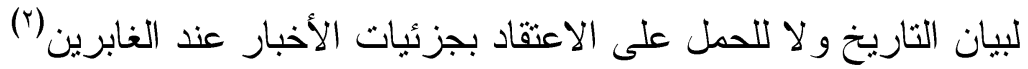
ومن هنا ندرك عمق الصلة بين الفكرتين فكرة خلف الله وفكرة الأستاذ الإمام وتلاميذه في قصص القرآن الكريم حتى قال الشيخ مصطفي صبري رحمه الله تعالى عن رسالة خلف الله ثلك : و إني أرى الرسالة المستتكرة وما سبقها في مصر من الأحداث و الفتن المماثلة

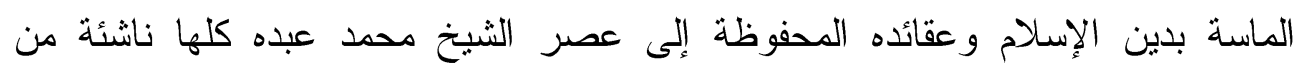
الأسس التى ابتدعها هذا الثيخ الملقب بالأستاذ الإمام، فلا مناص إذن للقضاء على تيار

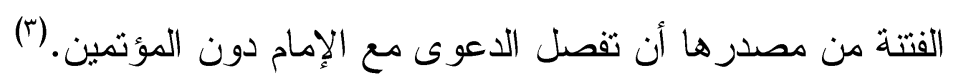
ويتضح لنا أيضاً حرص أمين الخولي المشرف على الرسالة المنحرفة على التصريح بأن الأن جامعة فؤاد التي رفضت الرسالة المنحرفة هذه نرفض اليوم ما ان يقرره الشيخ محمد

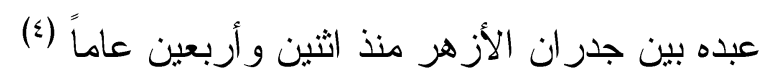

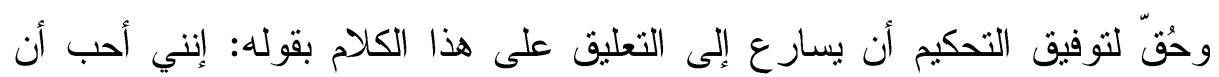
ألفت النظر إلى نقطة الخطورة فيها تلك هي قوله أن الأستاذ الإمام محمد عبده انتهى إلى لى له مثل هذه الآراء منذ اثثين وأربعين عاماً إذا كان هذا القول صحيحاً كما يؤكد الأستاذ الخولي فلنا أن نطلب تعليلاً لما صرنا إليه، و على المسئولين من رجال الدين أن أن يوضحوا

$$
\text { الموقف (ن) (ن) }
$$

إذن فقد ثبث أن هنالك علاقة وثقي بين ما تقدم به طالب رسالة الفن القصصي وبين ما ثردد في تقسير الإمام.

$$
\text { r }
$$

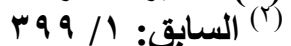

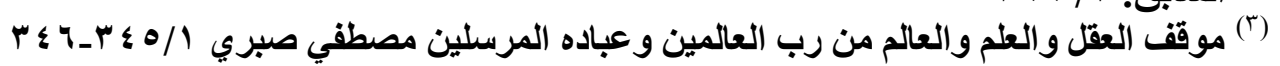

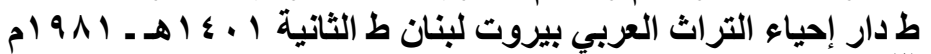

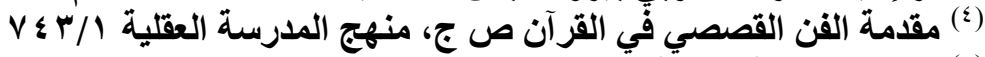

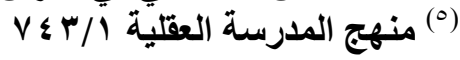


تفسير محمد عبده للطير الأبابيل

\section{خاتمة البحث}

نثبت في نهاية المطاف أهم ما توصل إلبه البحث من نتائج:

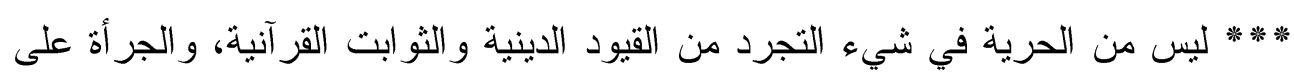

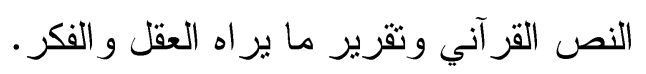

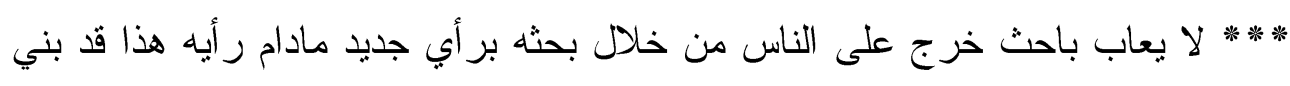
على قو اعد و اضحة وبر اهين مؤيدة، ولم بصادم في ذللك نقلا صحيحا و لا عقلا سليما. أما إذا كان الأمر على خلاف ذللك؛ فلا قيمة للقول مهما كانت درجة صاحبه من ولم الثهرة وذيوع الصيت ؛ إذ الحق لا يعرف بالرجال و إنما يعرف الرجال بالحق.

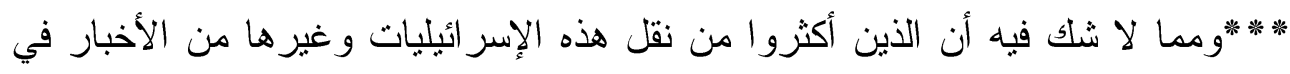
القصص القر آني وضعو ا الثوك في طريق المشتغلين بالتفسير، وذهبو ا بكثير من الأخبار الصحيحة بجانب ما رووه من قصص مكذوب و أخبار لا تصح. ليتنا نجد من بين علمائنا من يقوم بتجريد كتب التقسير من هذه الإسر ائيليات و الروايات

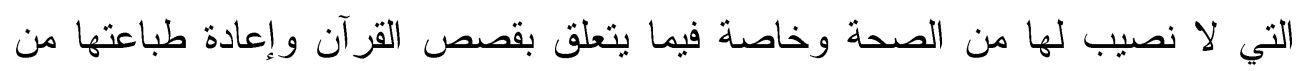
جديد لينسنى للناظر في كتاب الله تعالى أن يفهم القر آن بعيداً عن الخيالات و الأوهام. 


\section{أهم المر اجيع والمصادر}

القر آن الكريم. جلّ من أنزليه.

الأعلام للزر كلي ط دار العلم للملايين بيروت الطبعة الخامسة أيار (مايو) . 19 1.

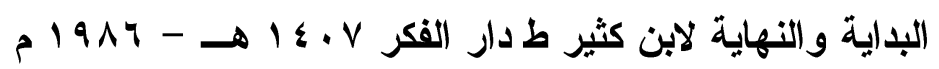
تفسير القرآن الحكيم المشتهر بتفسير المنار للأستاذ الإمام محمد عبده ط دار الإر المنار ط

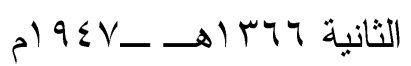

تفسير القرآن الكريم الثيخ محمود شلتوت طبع ونشر دار القلم بالقاهرة.

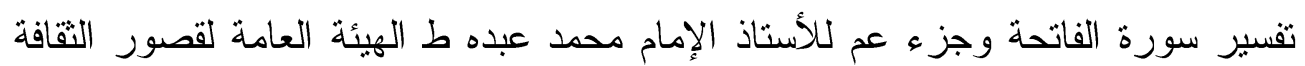

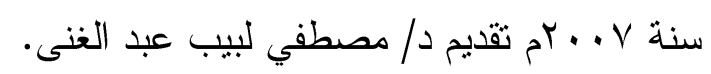

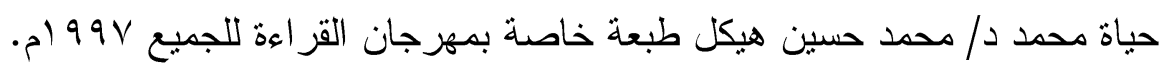

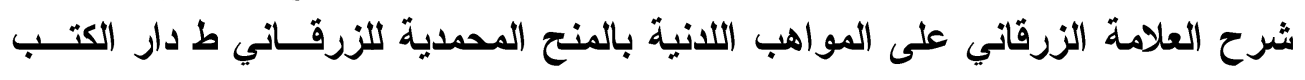

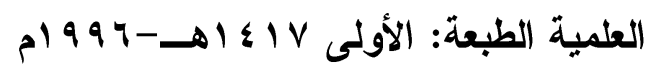
الثيخ عبد الرحمن تاج وبحوث قر آنية ولغوية لأبى بكر عبد الرهائ الرازق طا المكتب الثقافي

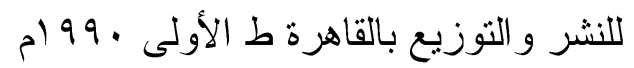

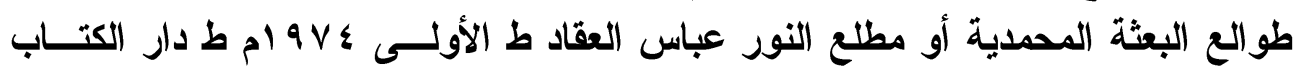

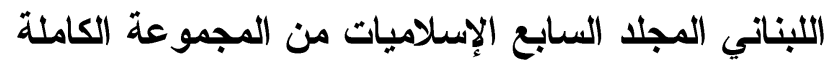

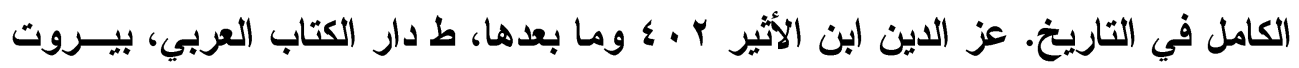

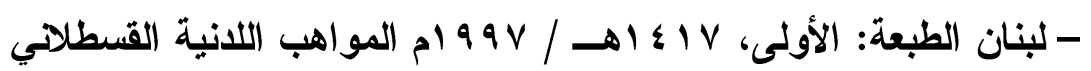
مجلة الرسالة تحقيق أحمد حسن الزيات العدد رقم عشرة مجة محة

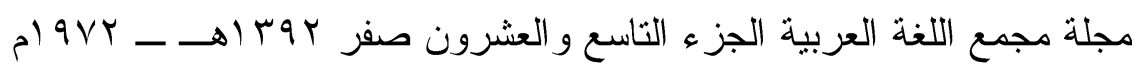

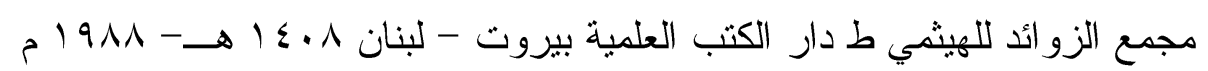

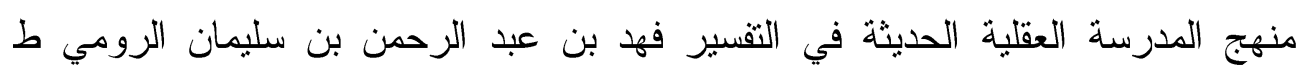

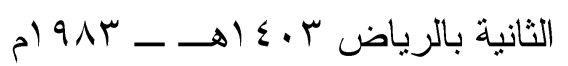
موقف العقل و العلم و العالم من رب العالمين و عباده المرسلين مصطفي صبري ط دار

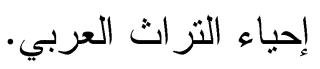

